\title{
Feathered Fibres of Human Soleus Muscle
}

\author{
Fibras Penniformes del Músculo Sóleo Humano
}

Joshi, S. S.; Joshi, S. D. \& Kishve, P. S.

JOSHI, S. S.; JOSHI, S. D. \& KISHVE, P. S. Feathered fibres of human soleus. Int. J. Morphol., 28(1):239-242, 2010.

SUMMARY: The large size of superficial group of muscles of back of leg is a characteristic feature of the musculature of man being related directly to its erect posture and mode of progression. Triceps surae is one of the powerful muscles of the body after Gluteus maximus and Quadriceps femoris. To make the muscle more powerful nature has devised a unique method of packing the fibers in a small space by pennation. There exists a bipenniform mass as a peculiarly human feature. Its feathered fasciculi arise from the deep (anterior) surface of the soleus muscle. Most of the textbooks of Anatomy and the available literature on the triceps surae or the tendoachillis do not appreciate and describe this fascinating aspect of the muscle. It was Schafer et al. (1923) who gave a detailed account of this muscle. Standring et al. (2005) have also described this muscle in great detail. We have studied the unique features of this part of soleus muscle. Bipennate arrangement was seen in $86 \%$ (right- $83 \%$; left- $89 \%$ ); and its maximum width was found to be $3.63 \mathrm{~cm}$ (Rt-3.71 cm; Lt $3.55 \mathrm{~cm}$ ). Median tendinous septum was directed backwards and medially. Thus this muscle will further increase the power of contraction of soleus, which is so very important for a bipedal gait.

KEY WORDS: Soleus muscle; Triceps surae muscle; Bipennate fibres.

\section{INTRODUCTION}

It is a well known fact that assumption of erect posture in man has led to very significant and drastic changes, especially so in relation to the evolution of brain and rearrangements in the musculoskeletal system. Soleus as its name indicates has the form of thick flat plate (Schafer $e t$ al., 1923). Gluteus maximus, the largest antigravity muscle which helps to raise the trunk at the hip and the muscles of the calf assume a special significance to maintain the body erect and help other muscles in balancing the body in various stances.

Plantar flexors are four times more powerful than the dorsiflexors of the ankle. The difference between these two groups of muscles is much less in anthropoids. In the primitive tetrapods a strong set of muscles was required to extend the foot at the ankle so as to raise the weight of the body from the ground and to give the forward push in progression (Schafer et al.). Soleus is more concerned with steadying the leg on the foot in standing. This postural role is suggested by its high content of Type I muscle fibres, which in many adult mammals approaches 100\% (Standring et al., 2005). During symmetrical standing soleus is continuously active, whereas, gastrocnemius is recruited only intermittently. High heels by introducing an element of instability increase activity in all the three muscles, especially soleus (Basmajian, 1985).

\section{MATERIAL AND METHOD}

One hundred and fourteen (Rt-60; Lt-54) lower limbs available in this department were dissected. Superficial group of calf muscles were dissected and the medial and lateral heads of gastrocnemius were cut near their origin and reflected inferiorly. Soleus was also cut from its tibial and fibular attachment and turned inferiorly exposing the deep surface of the muscle. Presence or absence of bipennate muscle fibres on the deep surface of soleus was noted. When present, its maximum width was measured. Variations, if any, were observed and photographed. Central septum of insertion of this bipennate muscle was exposed and its direction noted. This was confirmed by cutting transverse sections of the muscle triceps surae. 


\section{RESULTS}

In three cases there was unipennate arrangement of fibres (Fig. 1A). Bipennate arrangement was seen in $86 \%$ (right-83\%; left-89\%) (Fig. 1B). In one case we observed the presence of a double bipennate muscle (Fig. 1C).
Maximum width of bipennate muscle was found to be $3.63 \mathrm{~cm}$ (Rt-3.71cm; Lt-3.55cm). Median tendinous septum was directed backwards and medially (Figs. 2B and $2 \mathrm{C}$ ).

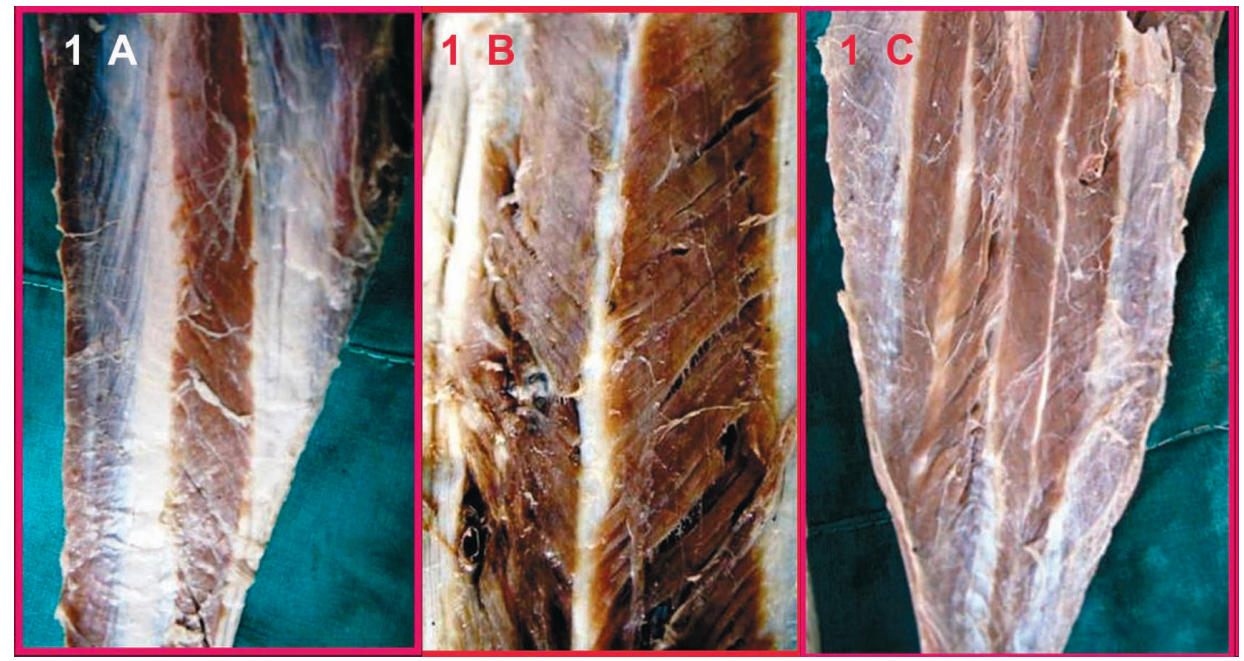

Fig. 1. A. Showing a unipennate arrangement of deep fibres of soleus muscle. B. Deep surface of soleus showing a well developed bipennate muscle with a well defined central tendon. C. Deep surface of soleus showing the presence of double bipennate muscle.

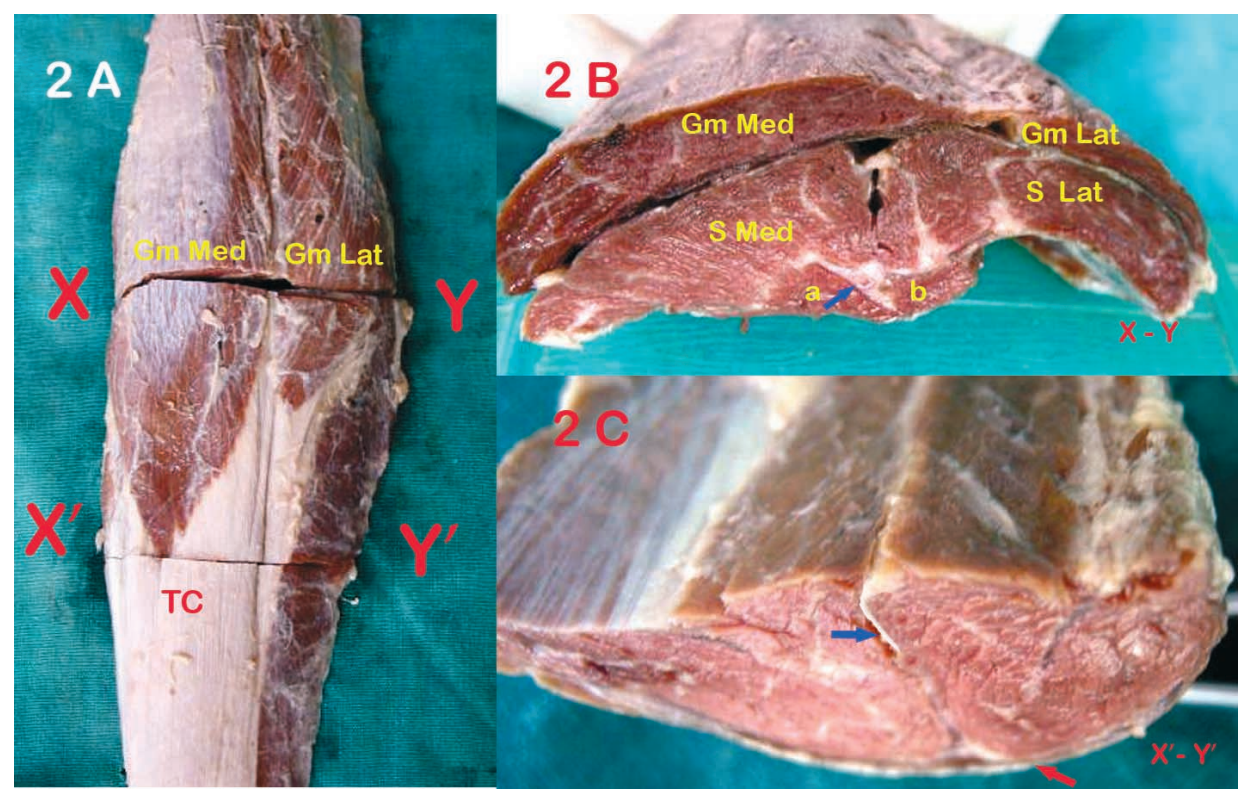

Fig. 2. A. Right calf muscles viewed from the back showing two transverse sections X-Y: through upper part of Gastrocnemius and soleus, $X^{\prime}-Y^{\prime}$ : through lower part of Gastrocnemius and soleus. B. Section at the level of X-Y showing: Gm Med- Medial head of Gastrocnemius; Gm Lat- Lateral head of Gastrocnemius S Med- Medial head of soleus; S Lat - Lateral head of soleus a and b : Medial and lateral parts of the bipennate muscle mass respectively. The blue arrow shows the septum within the bipennate mass being directed backwards and medially. C. Section at the level of X'-Y' showing Red arrow indicates aponeurosis of Gastrocnemius Blue arrow showing median septum of bipennate muscle mass in transeverse section. 


\section{DISCUSSION}

The large size of the superficial group of muscles of the back of leg is one of the most characteristic features of musculature of man (Standring et al.). The gastrocnemius, originally a muscle of the fibular side of the leg, must be considered in view of its phylogenetic history and development in the human subjects. Lateral head of gastrocnemius and soleus appear first in lower mammals and both are a derivative of the earlier lateral head of gastrocnemius (Schafer $e t$ al.). Triceps surae is a powerful muscle of the body only next to gluteus maximus and quadriceps femoris (Kapandji, 1987). The lateral head of gastrocnemius and soleus are so largely developed that they have come to overlap the digital and tibial tarsal flexors and popliteus muscle. In man it has been carried further by the extension of the attachment of soleus to tibia; and with medial expansion of these muscles and consequent alteration in their axis of pull the calcaneus has been displaced more directly under the talus (Schafer et al.).

Soleus from its fibular attachment has acquired additional powerful purchase from the tibia and the tendon of triceps surae becomes the thickest and the strongest tendon of body (a man weighing $100 \mathrm{~kg}$ may require a force of 300 $\mathrm{kg}$ to push off from the ground). Achillis tendon is the strongest tendon in the body and can withstand forces of approximately upto $1000 \mathrm{~kg}$ in the adults. It has a breaking strain of more than 2000 pounds per inch square (Corrigan \& Maitland, 1994).

The medial part of soleus has distinct functions: it is both a strong mover of the foot on the leg and a stabilizer of the leg on the foot. The main dynamic and static flexor is the medial part of soleus which is primarily responsible for plantar flexion - the activity that is used to restrain forward momentum of the body. The lateral part of soleus gives little power to moving the ankle and it is largely a stabilizer, especially when the platform is unstable (Basmajian).

It is suggested that the deep feathered fibres (bipennate mass) on the deep surface of the human soleus should be considered as a normal constituent of this large and powerful muscle, as it is constantly observed in over $85 \%$ individuals. This essentially will enhance the power of contraction or pull of soleus on the calcaneus through its median septum and the tendocalcaneus.

Thus further bulk has been added to the soleus in the form of feathered fasciculi on its anterior or deep surface as we have seen in the present study. This is gaining more prominence by becoming a double bipennate muscle.

Calf muscles keep the vertical column of the body erect, preventing its tendency to fall forwards. By strongly plantar flexing and pulling at the calcaneus they raise the column above the ground and help other muscles in the propulsion of the body. Soleus also squeezes the venous lakes and pumps the blood against gravity, acting as a peripheral heart. They act as postural (soleus) and dynamic muscles (gastrocnemius). Hence, the triceps surae is a large muscle with the strongest tendon which has increased its purchase from the fibula onto the tibia also.

JOSHI, S. S.; JOSHI, S. D. \& KISHVE, P. S. Fibras penniformes del músculo sóleo humano. Int. J. Morphol., 28(1):239-242, 2010.

RESUMEN: El gran tamaño de los grupos musculares superficiales de la parte posterior de la pierna es un rasgo característico de la musculatura del hombre siendo relacionado directamente con su postura erguida y el modo de progresión. El músculo tríceps sural es uno de los músculos más potentes del cuerpo después de los músculos glúteo magno y cuadríceps femoral. Para hacer al músculo más potente, la naturaleza ha ideado un método único de empaquetamiento de las fibras en un pequeño espacio por pennación. Existe una masa bipenniforme como una característica peculiarmente humana. Los fascículos pennados surgen desde la superficie profunda (anterior) del músculo sóleo. La mayoría de los textos de Anatomía y la literatura disponible sobre el músculo tríceps sural o el tendón de Aquiles no se aprecia ni se describe este aspecto fascinante que tienen los músculos. Fue Schafer (1923) quien dió una detallada descripción del músculo sóleo y posteriormente, Standring et al. (2005) también describieron detalladamente al músculo. Estudiamos las características únicas de esta parte del músculo sóleo, observando una disposición bipenniforme en el 86\% de los casos (derecha 83\%; izquierda 89\%). El ancho máximo del músculo fue de $3,63 \mathrm{~cm}$ (derecha $3,71 \mathrm{~cm}$; izquierda $3,55 \mathrm{~cm}$ ). El septo tendinoso mediano se dirigió hacia posterior y medial, aumentando así aún más el poder de contracción del músculo sóleo, el cual es muy importante para la bipedestación.

PALABRAS CLAVE: Músculo sóleo; Músculo tríceps sural; Fibras bipennadas. 


\section{REFERENCES}

Basmajian, J. V. Muscles alive: Their functions revealed by electromyography. $5^{\text {th }}$ Ed. Baltimore, Williams \& Wilkins, 1985. pp.334-41.

Corrigan, B. \& Maitland, G. D. Musculoskeletal sports injuries. $1^{\text {st }}$ Ed. Boston, Butterworth-Heinemann, 1994. pp.180-6.

Kapandji, I. A. The physiology of joints. $5^{\text {th }}$ Ed. Edinburgh, Churchill Livingstone, 1987. pp.206-9.

Schafer, E. S.; Symington, J. \& Bryce, T. H. Quain's Elements of Anatomy. Part II. 11th Ed. New York, Longman's Green and Co., 1923. pp.67-70.

Standring, S.; Ellis, H.; Healy, J. \& Johnson D, Williams A. Gray's Anatomy. The anatomical basis of clinical practice. $39^{\text {th }}$ Ed. New York, Elsevier, 2005. pp:1499500.
Correspondence to: Joshi, S. S.

Department of anatomy

Rural Medical College

Pims, Loni, 413736

Tal-Rahata, Dist-Ahmednagar

INDIA

Phone: 02422- 273600

Email: sdjoshi_2003@hotmail.com

Received: 14-02-2009

Accepted: 30-11-2009 